\title{
THE ENERGY COST OF AN 80 KM RUN
}

\author{
W. S. MYLES, MSc, PhD \\ Defence and Civil Institute of Environmental Medicine, 1133 Sheppard Avenue West, \\ P. O. Box 2000, Downsview, Ontario M3M $3 B 9$
}

\begin{abstract}
Data was collected from two men who attempted an $80 \mathrm{~km}$ run. Measurements of aerobic power $\left(\mathrm{VO}_{2} \max \right)$ and determinations of heart rate (HR) and submaximal oxygen consumption $\left(\mathrm{VO}_{2}\right)$ during treadmill running were carried out one week before the run. Throughout the $80 \mathrm{~km}$ run, HR was recorded by telemetry and used together with the laboratory data to estimate $\mathrm{VO}_{2}$ as a percentage of $\mathrm{VO}_{2} \max$. One subject completed the $80 \mathrm{~km}$ distance at $58 \%$ of $\mathrm{VO}_{2} \max$, the other subject, operating at $74 \%$ of $\mathrm{VO}_{2} \max$, was obliged to retire after $55 \mathrm{~km}$. The data in this and other studies indicate that the high energy costs reported for the marathon $\left(70-85 \%\right.$ of $\mathrm{VO}_{2}$ max) cannot be sustained over the $80 \mathrm{~km}$ distance but that about $60 \%$ of $\mathrm{VO}_{2} \max$ can be continued for seven hours and longer.
\end{abstract}

\section{INTRODUCTION}

Whereas there may be a biomechanical limit for running speed, the extent of human endurance has not yet been defined when performance is measured in terms of the distance covered at a given speed. Athletes now compete regularly in "ultramarathons" of $80 \mathrm{~km}$ and $160 \mathrm{~km}$ with new records established every year. Success in these events requires not only a high aerobic power $\left(\mathrm{VO}_{2}\right.$ max) but also the ability to utilize a high percentage of $\mathrm{VO}_{2}$ max for prolonged periods.

Although there have been many investigations of the marathon event (Costill and Fox 1969, Costill et al 1971, Maron et al 1976, Wyndham et al 1969), there is little published data concerning the performance of runners over longer distances, $\left(O^{\prime} \mathrm{Hara}\right.$ et al 1977). This paper presents a study of two runners who attempted the $80 \mathrm{~km}$ distance and compares their energy expenditures with values reported for the marathon (Costill and Fox 1969, Costill et al 1971, Maron et al 1976) and for the $160 \mathrm{~km}$ distance (O'Hara et al 1977). The specific objective was to determine whether the high energy expenditures reported for the marathon event in the above three papers could be sustained over longer distances.

\section{METHOD}

Two men ' $W$ ' and ' $G$ ', aged 37 and 32 years, respectively, had been involved as athletes in long distance running for about 10 years and had competed in several marathons $(42.4 \mathrm{~km})$. This was the first time that either of them had attempted the $80 \mathrm{~km}$ distance.

Preliminary testing was carried out in the laboratory about one week before the $80 \mathrm{~km}$ run. Aerobic power
$\left(\mathrm{VO}_{2}\right.$ max) was measured on each subject using a treadmill, the Beckman Metabolic Measurement Cart (Wilmore et al 1976) and a Cambridge ECG. They both achieved $\mathrm{VO}_{2} \max$ at $16 \mathrm{~km} / \mathrm{hr}$, ' $\mathrm{W}$ ' with a $2 \%$ and ' $\mathrm{G}$ ' with a $4 \%$ grade. Data collected during submaximal treadmill running was used to determine the relationship between oxygen consumption and heart rate for each subject.

The $80 \mathrm{~km}$ run was staged to raise money for charity and was not a competitive event. They ran on a level road surface; the lap distance was $\mathbf{3 9 0}$ metres and a total of 205 laps constituted the $80 \mathrm{~km}$ distance. Lap times were recorded for each runner. The run was held in November starting at $\mathbf{0 8 . 3 0} \mathrm{hr}$. Ambient temperature and weather conditions throughout the day were recorded and the core temperature of each subject was measured using a radio pill (Ackles et al 1976) swallowed 20 minutes before the run. Core temperatures were measured one hour after the start of the run and at hourly intervals thereafter. The subjects were provided ad libitum with a commercially available drink containing glucose and electrolytes, "Body Punch"" . During the run, heart rate was recorded every 2-3 laps using a Siemens Telecust 36 telemetry system. The laboratory data and heart rates measured during the run allowed an estimate of the energy cost of the run.

\section{RESULTS}

Aerobic power for subjects ' $W$ ' and ' $G$ ' was 61.3 and $68.5 \mathrm{ml} / \mathrm{kg} \mathrm{min}$, respectively. The relationship between heart rate $(\mathrm{HR})$ and oxygen consumption $\left(\mathrm{VO}_{2}\right)$ during submaximal treadmill running is shown by the equations:

$$
\begin{aligned}
& \mathrm{VO}_{2}=0.48 \mathrm{HR}-29.78 \text { for subject ' } W \text { ', } \\
& \mathrm{VO}_{2}=0.72 \mathrm{HR}-71.9 \text { for subject ' } \mathrm{G} \text { '. }
\end{aligned}
$$

\footnotetext{
* Manufactured by Starting Line Sports, PO Box 8, Mountain View, California 94042.
} 
Since the weather conditions were wet for much of the $80 \mathrm{~km}$ run and ambient temperatures were between $15-18{ }^{\circ} \mathrm{C}$ for the entire period, the runners did not have to contend with any environmental heat stress, the highest core temperature recorded being $38.3^{\circ} \mathrm{C}$ (Table 1). Body weights measured before and after the run indicated that subject ' $W$ ' lost $1.8 \mathrm{~kg}$ and subject ' $\mathrm{G}$ ' lost $2.6 \mathrm{~kg}$.

\section{TABLE 1}

Core temperatures during the $\mathbf{8 0} \mathbf{~ k m}$ run

\begin{tabular}{lll}
$\begin{array}{l}\text { Elapsed } \\
\text { Time } \\
\text { (hours) }\end{array}$ & \multicolumn{2}{c}{ Core temperature $\left({ }^{\circ} \mathrm{C}\right)$} \\
& Subject ' $W$ ' & \\
1 & & Subject 'G' \\
2 & 38.1 & 38.2 \\
3 & 38.0 & 38.2 \\
4 & 38.3 & 37.8 \\
5 & & 37.8 \\
6 & & 37.6 \\
\end{tabular}

Running speeds for both subjects declined as distance covered increased (Fig 1). Subject ' $W$ ' had an average running speed of $12.1 \mathrm{~km} / \mathrm{hr}$ until he was forced to retire after 140 laps $(54.6 \mathrm{~km})$. Subject 'G' completed the $80 \mathrm{~km}$ distance at an average speed of $11.6 \mathrm{~km} / \mathrm{hr}$ and his total time was $7 \mathrm{hr} 19 \mathrm{~min}$, including brief stops to adjust monitoring equipment, to drink and to relieve himself. His actual running time was $6 \mathrm{hr} 55 \mathrm{~min}$. The heart rates for both runners (Fig 2) fluctuated much

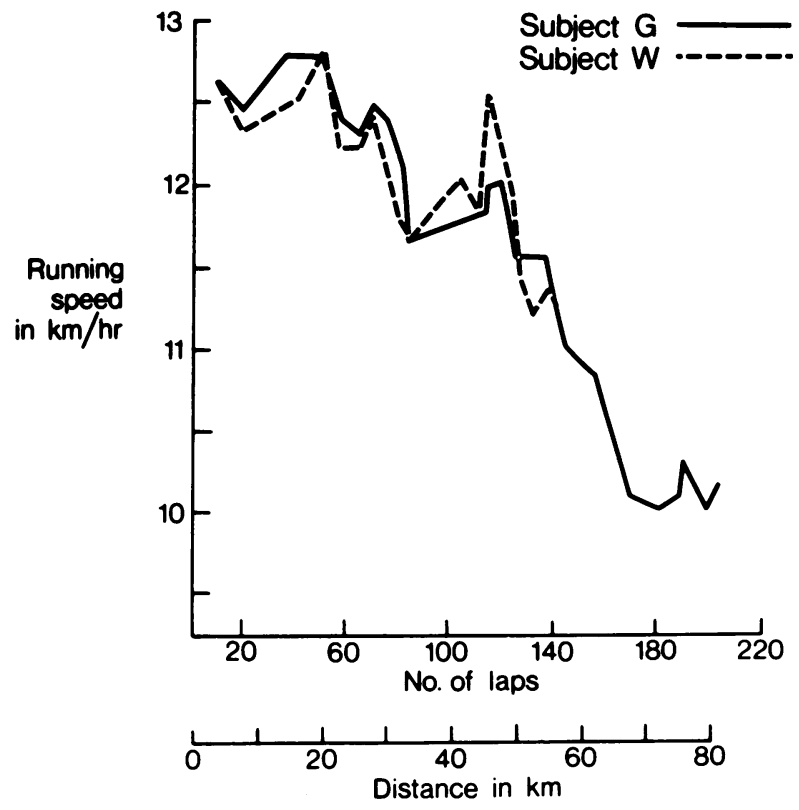

Fig 1: Running speed during the $80 \mathrm{~km}$ run.
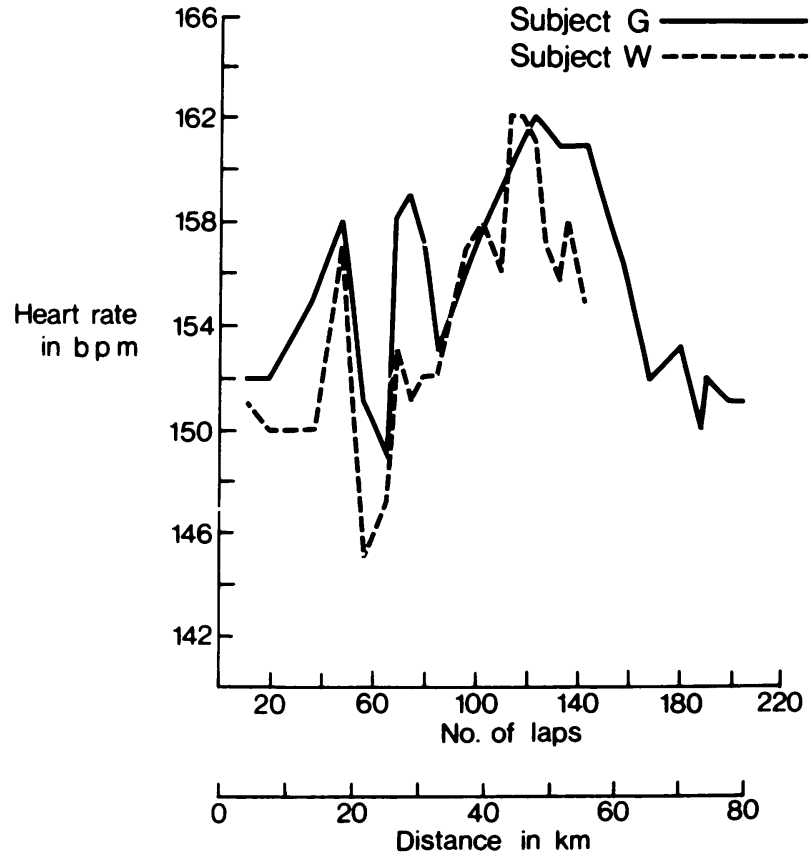

Fig 2: Heart rate during the $80 \mathrm{~km}$ run.

more than their running speeds and did not show the same declining trend with distance run.

The energy cost of the run was estimated from heart rate and expressed as a percentage of $\mathrm{VO}_{2} \max (\mathrm{Fig} 3$ ). Although running speed and heart rate (Figs 1 and 2) were only slightly different for the two runners, the energy cost as a percentage of $\mathrm{VO}_{2}$ max was strikingly higher for subject ' $W$ ' who ran at an average of $74 \%$ of his $\mathrm{VO}_{2} \max$ until he retired. Subject ' $\mathrm{G}$ ', on the other
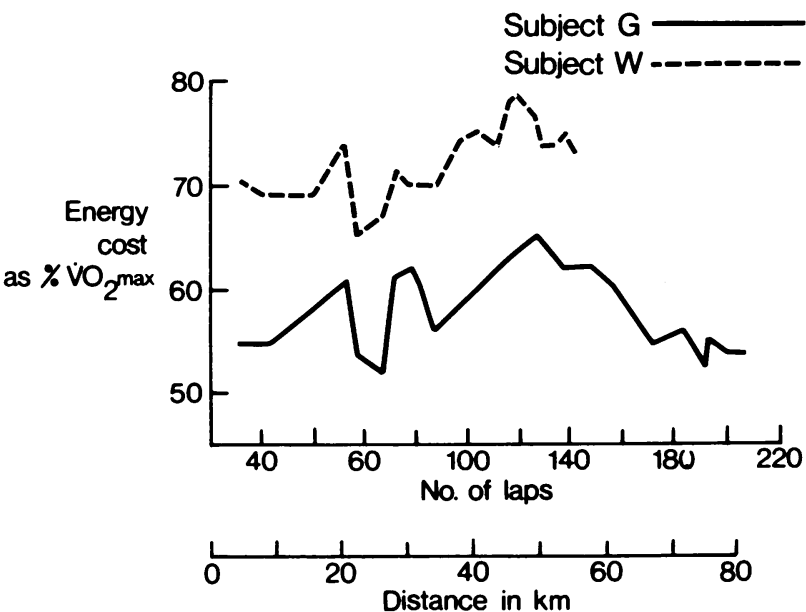

Fig 3: Energy cost expressed as $\% \mathrm{VO}_{2}$ max during the $80 \mathrm{~km}$ run. 
hand, completed the $80 \mathrm{~km}$ distance at an average of $58 \%$ of his maximum capacity.

\section{DISCUSSION}

While subject ' $G$ ' completed all 205 laps, subject ' $W$ ' was forced to retire after 140 laps. The explanation for the success of subject ' $G$ ' is most clearly indicated in Fig 3 which clearly shows that he was operating at a considerably lower percentage of his $\mathrm{VO}_{2}$ max. Whereas subject ' $W$ ' was unable to sustain $74 \%$ of $\mathrm{VO}_{2}$ max for more than $54.6 \mathrm{~km}$ (140 laps), subject $\mathrm{G}$ could maintain a running pace that represented $58 \%$ of his maximum capacity for the entire distance.

In this study, heart rate was used as an indirect measure of oxygen consumption and should therefore reflect variations in running speed. The observation that heart rate did not decrease with running speed (Figs 1 and 2) may have been due to hyperthermia or some departure from homeostasis. On the other hand, the changes in core temperature and body weight were not sufficiently different in the two runners to explain why subject ' $W$ ' was unable to complete the $80 \mathrm{~km}$ distance. The limiting factor in prolonged exercise is often the supply of metabolic fuel and the rate at which glycogen is depleted is a function of the intensity of exercise (Hermansen et al 1967). Subject ' $G$ ', running at only $58 \%$ of his $\mathrm{VO}_{2}$ max, was probably able to make more efficient use of his muscle glycogen stores than subject ' $W$ ' operating at a much higher intensity.

Although Costill et al (1971) found no correlation between $\mathrm{VO}_{2} \max$ and best marathon performance for 27 runners, all of them had high values for $\mathrm{VO}_{2} \max$ ranging from 63.5 to $78.1 \mathrm{ml} / \mathrm{kg} \mathrm{min}$. In this study, only subject ' $G$ ' had a $\mathrm{VO}_{2}$ max which was within this range. Superior performance in long distance running requires both a high $\mathrm{VO}_{2} \max$ and the capacity to utilize a high percentage of $\mathrm{VO}_{2} \max$ for long periods of time (Costill and Fox 1969). Maron et al (1976) reported that the energy expended during a marathon event represents $70-85 \%$ of $\mathrm{VO}_{2} \max$ and $\mathrm{O}^{\prime} \mathrm{Hara}$ et al (1977) found that the energy expenditure by a subject who ran $160 \mathrm{~km}$ in 19 hours and 37 min was $59 \%$ of his $\mathrm{VO}_{2} \max$. Although subject ' $G$ ' expended only $58 \%$ of his maximum capacity, he was sure that he had not fully extended himself. This seems likely since he was attempting the $80 \mathrm{~km}$ distance for the first time and lacked the stimulus of athletic competition.

The data presented in this study indicate that the high energy cost reported for the classical marathon event (Costill and Fox 1969, Costill et al 1971, Maron et al 1976), representing $70-85 \%$ of $\mathrm{VO}_{2}$ max, cannot be sustained over longer distances. On the other hand, energy expenditures which are equivalent to about $60 \%$ of $\mathrm{VO}_{2}$ max can be continued for seven hours and much longer (O'Hara et al 1977)

\section{ACKNOWLEDGEMENT}

The author wishes to acknowledge the medical support provided by Dr. Lyle Howlett and Dr. Hugh Mclsaac and to express his admiration for the two runners.

\section{REFERENCES}

Ackles K. N., Howat M. R., Ulrichsen, J. E., and Pope, J. I. 1976. "A hand-held radio pill temperature readout". D.C.I.E.M. Rep.No.76-X-50.

Costill D. L., and Fox E. L. 1969. "Energetics of marathon running", Med.Sci.Sports 1: 81-86.

Costill D. L., Branam G., Eddy D., and Sparks K. 1971. "Determinants of marathon running success". Int.Z.Angew. Physiol. 29: 249-254.

Hermansen L., Hultman E., and Saltin B. 1967. "Muscle glycogen during prolonged severe exercise". Acta Physiol. Scand. 71: 129-139.

Maron M. B., Horvath S. M., Wilerson J. E., and Gliner J. A. 1976. “Oxygen uptake measurements during competitive marathon running". J.Appl.Physiol. 40: 836-838.

O'Hara W. J., Allen C. L., Shepard R. J., and Gill J. W. 1977. "LaTulippe - A case study of a one hundred and sixty kilometer runner". Brit.J.Sports Med. 11: 83-87.

Wyndham C. H., Strydom N. B., VanRensburg A. J. and Benade, A. J. S. 1969. "Physiological requirements for world-class performance in endurance running". S.Afr.Med.J. 43: 996-1002.

Wilmore J. H., Davis J. H. and Norton A. C. 1976. "An automated system for assessing metabolic and respiratory function during exercise." J.Appl.Physiol. 40: 619-624. 